\title{
DCIS in Male and Aged Women with Comorbidities
}

\author{
Natalia Krawczyk ${ }^{1 *}$, Tanja Fehm¹, Maggie Banys-Paluchowski ${ }^{2,3}$ \\ 'Department of Obstetrics and Gynaecology, University of Duesseldorf, Moorenstr. 5, 40225 Duesseldorf, Germany \\ 2Department of Obstetrics and Gynaecology, University Hospital Schleswig-Holstein, Campus Lübeck, Ratzeburger Allee 160, \\ 23562 Lübeck, Germany \\ ${ }^{3}$ Medical Faculty, University of Duesseldorf, Duesseldorf, Germany
}

${ }^{*}$ Corresponding author: Dr. Natalia Krawczyk, MD Department of Obstetrics and Gynaecology University of Duesseldorf, Moorenstr. 5 40225 Duesseldorf, Germany

E-Mail: natalia.krawczyk@med.uni-duesseldorf.de

\begin{abstract}
Rezumat
Rata de incidență a carcinomului ductal in situ (CDIS) a crescut rapid în ultimele două decade la toate grupele de pacienți, inclusiv la barbații şi femeile în vârstă. CDIS la femeile în vârstă are un prognostic excelent şi riscul de recurență locală este mai scăzut comparativ cu pacientele tinere. Datorită faptului că radioterapia adjuvantă după tumorectomie şi tratamentul hormonal nu influențează semnificativ supraviețuirea pe termen lung, se poate lua în considerare o de-escaladare a tratamentului, în special la femeile cu leziuni de grad 1 şi comorbidități asociate. CDIS pur la bărbați este o patologie foarte rară, reprezentând $5 \%$ din totalul cancerelor de sân la bărbat. Cel mai comun tip de CDIS care apare la bărbați este carcinomul papilar, de grad scăzut sau intermediar, ce se dezvoltă din ductele mari centrale, pentru că sânul masculin nu prezintă în mod normal lobuli şi unităti lobulare terminale (TDLU). CDIS de grad înalt, la barbat, este rar şi se asociază în general cu hiperestrogenismul sever, cum se întamplă în ginecomastie. Cei mai frecvenți factori de risc la bărbați sunt: vârstă înaintată, nivele crescute de estrogen şi istoric familial pozitiv. CDIS la bărbați este în general o patologie detectabilă clinic. Cele mai comune simptome descrise în literatură sunt reprezentate de o masă palpabilă, frecvent chistică, care coexistă sau nu cu o secreție mamelonară (frecvent sanguinolentă, rar seroasă) sau cu o modificare a mamelonului. Tratamentul standard pentru bărbații cu CDIS este mastectomia simplă, fără radioterapie. Prognosticul este excelent.
\end{abstract}


Cuvinte cheie: carcinom ductal in situ, bărbați, femei în vârstă, comorbidități

\section{Abstract}

The incidence rates of ductal carcinoma in situ (DCIS) have increased rapidly over the last two decades in all patient groups including older women and men. DCIS in aged women has an excellent prognosis and the risk of local recurrence is lower compared to younger patients. Since adjuvant radiation after lumpectomy and endocrine treatment do not significantly influence overall survival a de-escalation of treatment especially in case of grade 1 lesions in women with comorbidities can be considered. Pure DCIS in men is a very rare disease representing approximately $5 \%$ of all male breast cancers. The most common type of DCIS in men is a papillary carcinoma mostly of low or intermediate grade developing from large central ducts, since male breast typically lacks lobules and terminal duct-lobular units (TDLU). A male DCIS of high grade is rare and mostly associated with severe hyperestrogenism, e.g., in case of gynecomastia. The most common risk factors in men are increasing age, high estrogen levels and positive family history. DCIS in men is usually a clinically apparent disease. The mostcommon symptoms described in the literature are palpable, often cystic mass, coexisting or isolated nipple discharge (mostly bloody, in rare cases watery) or nipple alteration. A standard treatment among men with DCIS is a simple mastectomy without radiation. The prognosis is excellent.

Key words: ductal carcinoma in situ, male, aged women, comorbidities

\section{Introduction}

Ductal carcinoma in situ (DCIS) rates raised rapidly over the last two decades and the entity currently accounts for $20-25 \%$ of newly detected breast cancer (BC) cases (1). This increase is mostly due to mammographic screening widely available in many countries (2). However, the trend is being observed in all age groups (3) and both sexes (4), suggesting other factors should be considered as well. A lifetime risk of progression from DCIS to invasive breast cancer is not definitely known but it is estimated to be under $50 \%$ (5). In this review, we discuss the prevalence, clinical features, recommended treatment and prognosis of DCIS in two specific subgroups: male patients and aged women with comorbidities.

\section{DCIS in Aged Women with Comorbidities}

While the incidence of DCIS is rising in developed countries and the life expectancy in general is increasing as well, more older women will face the diagnosis of DCIS and be confronted with the question whether a de-escalation of the locoregional therapy may be a reasonable option (6). While there is no consensus on the exact definition of "older" or "elderly", traditionally patients aged 65 years or older are referred to as "elderly" in the literature. Further, some authors differentiate between "early elderly" population (i.e., 65-74 years old) and "late elderly" (over 75 years) and one needs to bear in mind that while the chronological age is an important factor while planning diagnostics and therapy, it should always be considered in combination with comorbidities and performance status. For instance, a vulnerable 60-year-old patient with severe comorbidities may have shorter live expectation than a 70-year-old healthy person with good performance status. Current recommendations from the AGO Breast Committee define a "fit elderly patient" as a life expectancy of $>5$ years and acceptable comorbidities and "frail patients" as those with life expectancy of $<5$ years and substan- 
tial comorbidities (8-10). Importantly, the spectrum of possible comorbidities and their impact on oncological outcomes varies widely in the available literature. A number of medical and surgical conditions can negatively influence the surgical outcome and the quality of life during and after treatment and the presence of comorbidities has been shown to increase the risk of complications or even treatment-related death. The majority of available studies reported decreased chemotherapy use and inferior survival for patients with solid tumors presenting with comorbidities compared to those without, and most showed an increased rate of severe toxicity and increased treatment delays for patients with comorbidity (11). Typical comorbidities examined in oncological patients in previous studies were congestive heart failure, chronic obstructive pulmonary disease, diabetes mellitus, inflammatory bowel disease and some reported the so-called cumulative comorbidity, either using an index or total count of comorbidities (11). On the other hand, the potential benefit from oncological therapy needs to be weighed against the risk from other diseases and decision making is particularly challenging in the adjuvant setting because patients with comorbidity may not survive long enough to derive expected benefits from treatment.

Despite excellence prognosis following locally treated DCIS, a recent analysis of the SEER database has shown that risk of dying from breast cancer increased 3 -fold after a diagnosis of DCIS (12). While this risk is particularly high in younger women diagnosed with DCIS, it remains increased in older patients as well (standardized mortality ratio (SMR) < 40 years: 11.95, 40-49: 4.15, 50-59: 2.82, 60-69: 2.65 and 70-79: 3.72) (12). Therefore, the optimal management of DCIS in older patients and particularly those with comorbidities remains subject of ongoing debate.

\section{Epidemiology}

In a large population-based analysis including 1949 cases of pure DCIS treated with breast- conserving surgery (BCS) and radiation between 1994 and 2003 in Ontario, Canada, the median age at time of diagnosis was 56 years (13). Similarly, data from the Netherlands Cancer Registry confirm the median age of DCIS diagnosis as 57.4 years (14). $15.1 \%$ of patients were 70 or older and $5.2 \%$ were over 75 at time of diagnosis. Interestingly, this study has shown that DCIS patients had higher risk of breast cancer mortality (SMR 3.33), but lower risk of death from all other cancer combined (SMR 0.82) and from lung (SMR 0.74) and urogenital cancers (SMR 0.62) individually. When studying smaller age groups, the SMR for breast cancer decreased with increasing age (SMR 23.20 to SMR 1.91 for women aged 75 years, respectively) and, compared with the general female population, DCIS patients older than 50 years had lower all-cause mortality (SMR 0.88). In the manuscript, the authors discussed possible explanations of this puzzling finding and concluded that it is unlikely that the better life expectancy among DCIS patients $>50$ years is related to the DCIS itself. More plausible seems the impact of lifestyle characteristics as DCIS patients represent a generally healthy group of women. Specifically, lower risk of cardiovascular and respiratory-caused mortality as well as death from lung cancer are likely due to lifestyle factors (14). Another hypothesis is based on the screening bias, since women who adhere to mammographic screening programs and are therefore more likely to be diagnosed with DCIS seem to be more health-conscious and have less comorbidities (15). Hypothetically, women treated for DCIS may adopt a healthier lifestyle after their diagnosis, thus preventing the development or at least enabling earlier diagnosis and treatment of other diseases.

According to several studies, locoregional recurrence risk following diagnosis of pure DCIS is lower in older patients (13). Kong et al. reported long-term outcomes in a large population of DCIS patients treated with BCS and radiation in Ontario between 1994 and 2003 (13). Among those patients, young age at time of diagnosis was the strongest predictor 
of local recurrence, both invasive and in situ and the effect of age on recurrence risk was continuous. At 10 years, local recurrence rates were $11 \%$ for patients $>50$ years, $15 \%$ for $45-50$ years, and $25 \%$ for $<45$ years. Therefore, when treating older DCIS patients, and particularly those with low-risk disease, the overall context and life expectancy should be considered. Statistically, for women $\geq 70$ years old, the average expectation of remaining life is 16.7 years, decreasing to 9.8 years for those aged $\geq 80$ years old (16). In case of DCIS with an estimated 5-year disease specific survival of $>99 \%$, it seems reasonable to discuss treatment options on an individual basis.

\section{The optimal treatment of DCIS in older women}

Current guidelines recommend primary surgical treatment of DCIS that can be performed as lumpectomy or mastectomy, depending on extent of disease and patient's preferences (9, 17). For patients receiving breast-conserving surgery, adjuvant radiation or endocrine therapy can be offered. Postoperative radiation therapy can lower ipsilateral recurrence risk, both invasive and in situ, by about a half, but it does not influence overall survival, and the number needed to treat (NNT) is estimated as 9 (18). Therefore, according to recommendations issued by the AGO Breast Committee, when deciding to conduct or omit radiation patient's preferences and individual characteristics should be considered. In case of older patients wishing to receive radiation therapy, partial breast irradiation can be offered. Similarly, adjuvant endocrine therapy has no impact on survival but can reduce risk of ipsilateral and contralateral disease and the number needed to treat for any ipsilateral breast event is 15 (18), and again, the decision for or against endocrine treatment should be made on an individual basis, and consideration of risks and benefits is important (17). Several analyses have been conducted to specifically assess treatment effects in older patients with DCIS. In 2019, DeChant et al. examined follow up data from 18,451 patients $\geq 70$ years from the U.S. National Cancer Data Base (2004-2015) who underwent lumpectomy or mastectomy for DCIS (16). Women who underwent lumpectomy and radiation therapy or mastectomy had a slightly improved overall survival (OS), compared to patients after lumpectomy alone (HR 0.841). In case of grade 1 disease, lumpectomy + radiation or mastectomy was not associated with an OS benefit. The most pronounced improvement in survival was observed in patients with ER+ disease receiving endocrine therapy in addition to local treatment. The authors concluded that comorbidities, patient fitness, and individual preferences are critical factors when considering de-escalating therapy, but age alone should not preclude a patient from being recommended standard therapy for DCIS (16).

\section{DCIS in male}

DCIS in the male breast can be associated with invasive cancer (DCISAIC) or occur as a pure lesion. However, pure DCIS in male is a very rare disease with few cases and case series reported in the literature to date. Since anatomy of male breast differs from the female breast on the one side and men do not participate in screening mammography programs on the other side, histological features and clinical characteristics in male DCIS differ from DCIS in women.

\section{Epidemiology}

The incidence of pure DCIS among all male breast carcinomas varies in the literature between $1 \%$ and $17 \%$ with an average of approximately 5\% (19). This discrepancy is due to the rarity of this entity as well as lack of routine surveillance. Anderson et al. analyzed data from the Surveillance, Epidemiology, and End Results (SEER) database of the National Cancer Institute and reported male in situ carcinoma in 280 of 2984 male breast cancer cases $(9,4 \%)$ diagnosed between 1973 and 2001 (4). This analysis 
included lobular in situ carcinoma as well, however only six cases of this entity have been reported in this analysis (4). Similar to invasive BC, men with DCIS are mostly being diagnosed at older age compared to women (20). Detailed epidemiological data were provided by the same group on the basis of 209 cases of male in situ BC documented in the SEER database (1992-2001) (4). The median age at diagnosis was 62 years compared to 58 years in women with DCIS (4). In a large series of 84 pure DCIS cases in men by Hittmair et al. the median age at diagnosis was 65 years (21). In contrast, in a series of 31 pure DCIS in male reported by Cututli at al., median age at time of diagnosis was 58 years, ranging from 26 to 74 years with six patients younger than 40 years (22).

\section{Histomorphology}

Morphological differences between male and female breast tissue lead to distinct histopathological patterns and localization in breast cancer as well as DCIS. Most of BC cases in female patients develop within the terminal duct lobular units (TDLU) in the periphery of the breast (23). However, a male breast typically lacks lobules and TDLU's and differentiates these structures only in case of severe hyperestrogenism (24). Therefore, ductal structures in the male breast typically consist of a nipple and large central ducts, mostly of the papillary type (21). As a consequence, a very common pathological type of DCIS and invasive cancer in male is papillary carcinoma, an entity rather rare in female patients. On the other hand, lobular carcinomas (in situ and invasive) are extremely rare in male, since the normal male breast tissue lacks lobules as mentioned above. In the analysis of 209 cases from the SEER database treated between 1992 and 2001 the predominant pathological type of in situ BC in men was ductal non comedo type, diagnosed in 102 of 209 cases $(48.8 \%)$ followed by papillary in situ carcinoma reported in $23.4 \%$ cases ( 49 of 209) compared to $6.2 \%$ in female patients $(2,901$ of 46,929$)$ (4). In the series by Hittmair et al. the most common morphological type of DCIS was papillary carcinoma (46\%) followed by papillary/cribriform (27\%) and cribriform carcinoma (19\%) (21). These specific morphological types have also been reported in several other cases of male DCIS published to date $(22,25-30)$.

Pure DCIS in male is mostly of low or intermediate grade without comedonecrosis, whereas high grade DCIS is often associated with invasive BC (DCISAIC) (4,21). Single cases of high-grade pure DCIS have been reported in men with gynecomastia $(27,29$, 31 ), a condition mostly associated with elevated estrogen levels leading to differentiation of TDLU in male breast tissue. Therefore, high-grade DCIS is assumed to develop from epithelial cells of TDLUs, whereas low and intermediate grade lesions are thought to derive from epithelial cells of central ducts (21).

\section{Risk Factors}

Increasing age, hyperestrogenism and positive family history are the most common risk factor for development of male BC including DCIS. According to the literature, approx. 15$20 \%$ of male patients with $\mathrm{BC}$ have positive family history, whereas BRCA1 and 2 mutation, mostly the second, can be found in less than $10 \%$ of the reported cases (32). An estimated lifetime risk for $\mathrm{BC}$ in male carriers of BRCA2 mutation is $6 \%$ compared to $0.1 \%$ in general male population (33). Other genetic conditions associated with $\mathrm{BC}$ risk in male are Cowden and Klinefelter syndromes (34, 35). Lifestyle factors like alcohol consumption and higher economic status as well as obesity, probably as a cause of elevated estrogen levels, are also considered risk factors in male. Further conditions associated with hyperestrogenism or an imbalance between estrogen and testosterone like testicular dysfunction, intake of exogenous estrogens (i.e. in prostate cancer patients) or liver cirrhosis have been reported to increase BC risk among men as well (33). Interestingly, although gynecomastia is often caused by 
hyperestrogenism and has been described in several male BC od pure DCIS cases (22), there is no proven association between this condition and $\mathrm{BC}$ in male to date $(36,37)$.

\section{Clinical Presentation}

While DCIS in women is mostly asymptomatic and detected during routine mammographic screening or through mammography performed for other reasons, DCIS in men is usually a clinically apparent disease. The most common symptoms described in the literature are palpable, often cystic mass, coexisting or isolated nipple discharge (mostly bloody, in rare cases watery) or nipple alteration $(21,38)$. In a series by Hittmair et al. $58 \%$ of pure DCIS male patients presented with palpable mass and $35 \%$ with nipple discharge (21). A possible, very rare presentation of DCIS among men is Paget disease with typical eczematoid alteration of the nipple or nipple-areola complex (39-42).

A very common localization of male DCIS, in contrast to its female counterpart, is the central/retromamillary area. A usual mammographic presentation is a retromamillary mass or typical microcalcifications, however both findings can be obscured by coexisting gyneco- mastia. Figures 1-3 show examples of radiologic presentation of DCIS in male patients (Fig. 1-3). Sonographic imaging can show a cystic or solid mass, dilated ducts or no pathological findings.

\section{Optimal Treatment}

Due to its rarity most treatment strategies for DCIS in male are based on evidence gathered in female patients. Similar to DCIS in women, surgery represents the main treatment option. Since the resection of nipple-areola complex is necessary in most cases, there is no cosmetic advantage of retaining breast tissue in these patients and the standard surgery among men with DCIS is a simple mastectomy. However, several cases describing breast conserving surgery followed by the radiotherapy have been reported in the literature $(22,29)$. Similar to female DCIS, male patients treated with mastectomy do not need a radiotherapy. In case of mastectomy a sentinel node biopsy can be performed, especially among the highgrade cases with an increased risk of occult microinvasion. There is no solid evidence for systemic treatment with tamoxifen in pure DCIS of the male with only single cases described in the literature to date (40).

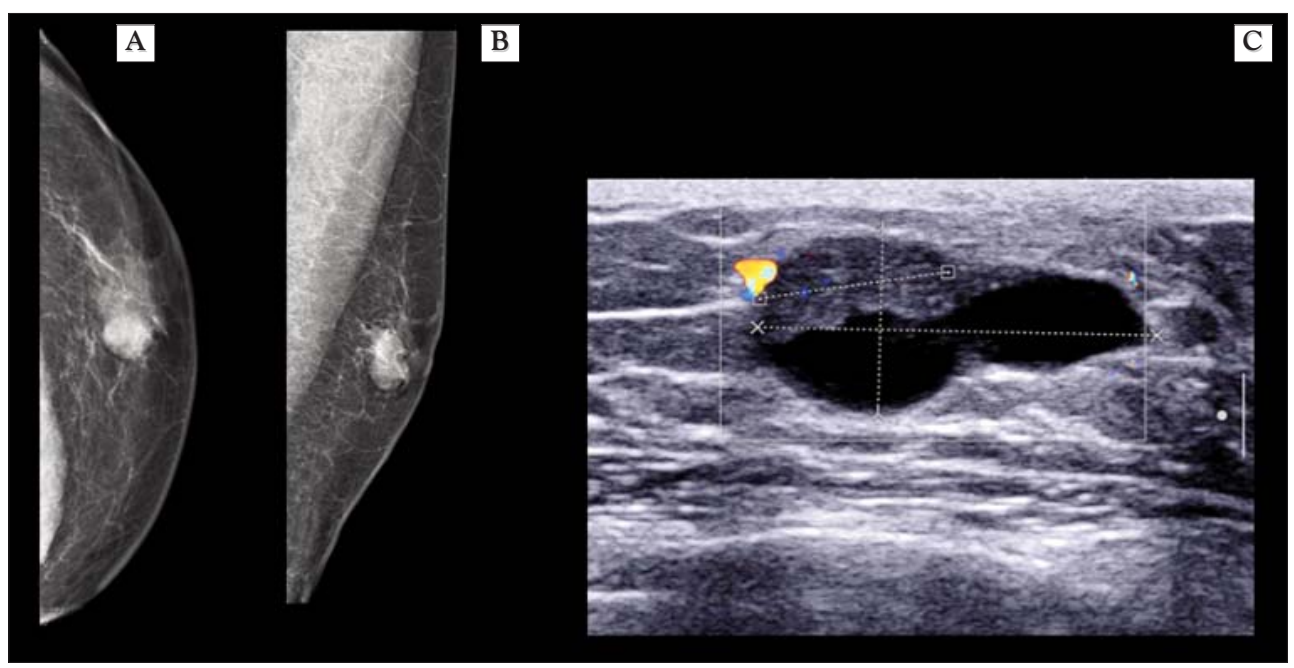

Figure 1. Solid-papillary DCIS of intermediate grade in a 43-year-old man, presenting with palpable retromamillary mass in the left breast. A circumscribed mass without microcalcifications was demonstrated in a mammogram (A/B). Ultrasound shows a cystic lesion with intracystic papillary structures (C) 


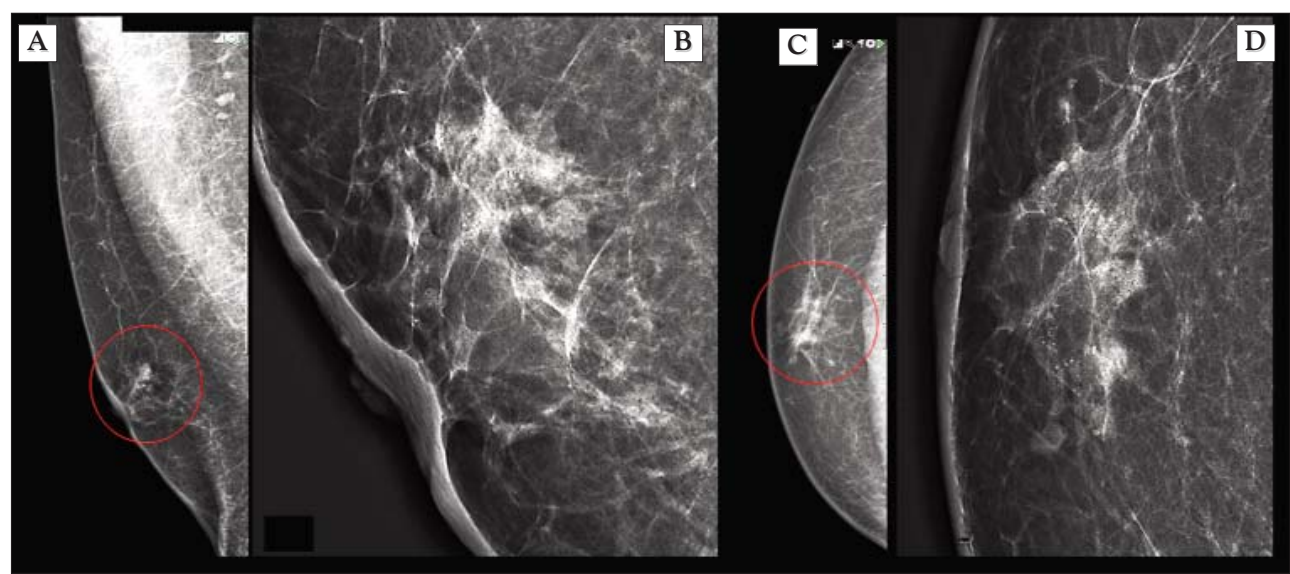

Figure 2. Suspicious microcalcifications in a 46-year-old man with high grade DCIS of the right breast, presenting with bloody nipple discharge (red circle, $\mathbf{A} / \mathbf{C}$ and magnification view $\mathbf{B} / \mathbf{D})$. Breast ultrasound showed no pathological findings. A core biopsy guided by mammogram confirmed the diagnosis

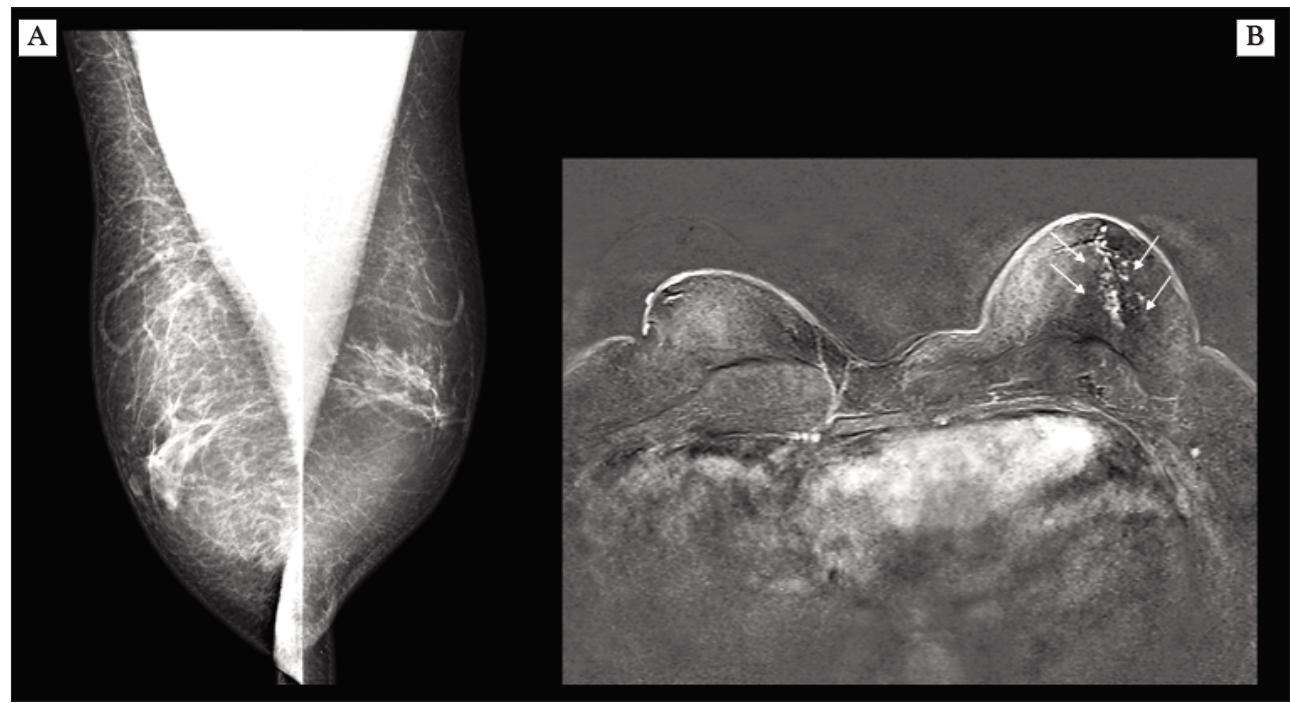

Figure 3. A case of solid-papillary low-grade DCIS of the left breast in a 63-year-old man presenting with bloody nipple discharge. (A) Mammogram without pathological findings with clinically apparent gynecomastia masks DCIS. Breast sonography showed no abnormalities. (B) Non-mass enhancement demonstrated upon breast MRI. Diagnosis was confirmed using MRI-guided vacuum-assisted biopsy

\section{Prognosis}

Similar to DCIS in female, DCIS among male patients has excellent prognosis. After surgical treatment with mastectomy, the risk of disease recurrence is minimal (4), whereas higher recurrence rates have been observed in cases treated by breast conserving surgery (22).

\section{Conclusions}

Due to its increasing incidence and ongoing discussion regarding optimal treatment, DCIS has become an important focus of oncological research. Pure DCIS in men remains an extremely rare entity and is usually treated similarly as DCIS in women. In aged women with comorbidities, de-escalation of surgical 
and adjuvant therapy remains subject of ongoing debate.

\section{Conflict of Interest}

Maggie Banys-Paluchowski: honoraria for lectures and participation in advisory boards: Novartis, Pfizer, Roche, Seagen pfm, Amgen GSK, Lilly, Onkowissen, Gilead, NK and TF declare no conflicts of interest.

\section{References}

1. van Seijen M, Lips EH, Thompson AM, Nik-Zainal S, Futreal A, Hwang ES, et al. Ductal carcinoma in situ: to treat or not to treat, that is the question. $\mathrm{Br}$ J Cancer. 2019;121(4):285-292.

2. Gotzsche PC, Jorgensen KJ: Screening for breast cancer with mammography. Cochrane Database Syst Rev. 2013(6):CD001877.

3. Kahler-Ribeiro-Fontana S, Pagan E, Magnoni F, Vicini E, Morigi C, Corso G, et al, Long-term standard sentinel node biopsy after neoadjuvant treatment in breast cancer: a single institution ten-year follow-up. Eur J Surg Oncol. 2021;47(4):804-812. Epub 2020 0ct 15.

4. Anderson WF, Devesa SS. In situ male breast carcinoma in the Surveillance, Epidemiology, and End Results database of the National Cancer Institute. Cancer. 2005;104(8):1733-1741.

5. Kramer BS, Croswell JM. Cancer screening: the clash of science and intuition. Annu Rev Med. 2009;60:125-37.

6. Badve SS, Gokmen-Polar Y. Ductal carcinoma in situ of breast: update 2019. Pathology. 2019;51(6):563-569.

7. Orimo $\mathrm{H}$, Ito $\mathrm{H}$, Suzuki T, Araki A, Hosoi T, Sawabe M. Reviewing the definition of "elderly". Geriatrics \& Gerontology. 2006;6(3):149-158.

8. AGO Breast Committee. Diagnosis and Treatment of Patients with Primary and Metastatic Breast Cancer. Recommendations 2021. www.ago-online.de. 2021.

9. Ditsch N, Kolberg-Liedtke C, Friedrich M, Jackisch C, Albert US, BanysPaluchowski M, et al. AGO Recommendations for the Diagnosis and Treatment of Patients with Early Breast Cancer: Update 2021. Breast Care (Basel). 2021;16(3):214-227.

10. Thill M, Friedrich M, Kolberg-Liedtke C, Albert US, Banys-Paluchowski M, Bauerfeind I, et al: AGO Recommendations for the Diagnosis and Treatment of Patients with Locally Advanced and Metastatic Breast Cancer: Update 2021. Breast Care (Basel). 2021;16(3):228-235.

11. Lee L, Cheung WY, Atkinson E, Krzyzanowska MK: Impact of comorbidity on chemotherapy use and outcomes in solid tumors: a systematic review. J Clin Oncol. 2011;29(1):106-117.

12. Giannakeas V, Sopik V, Narod SA: Association of a Diagnosis of Ductal Carcinoma In Situ With Death From Breast Cancer. JAMA Netw Open 2020; 3(9): :2017124.

13. Kong I, Narod SA, Taylor C, Paszat L, Saskin R, Nofech-Moses S, et al: Age at diagnosis predicts local recurrence in women treated with breastconserving surgery and postoperative radiation therapy for ductal carcinoma in situ: a population-based outcomes analysis. Curr Oncol. 2014;21(1): e96-e104.

14. Elshof LE, Schmidt MK, Rutgers EJT, van Leeuwen FE, Wesseling J, Schaapveld M. Cause-specific Mortality in a Population-based Cohort of 9799 Women Treated for Ductal Carcinoma In Situ. Ann Surg. 2018;267(5):952-958.

15. Hofer TP, Katz SJ. Healthy behaviors among women in the United States and Ontario: the effect on use of preventive care. Am J Public Health. 1996; 86(12):1755-1759.

16. DeChant CA, Thomas SM, Rosenberger LH, Fayanju OM, Greenup RA, Hwang ES, et al. Ductal carcinoma in situ in the elderly: what is the ideal treatment plan? J Unexplored Med Data 2019;4:2.

17. NCCN Clinical Practice Guidelines in Oncology, Breast Cancer, Version
5.2021 - June 28, 2021, NCCN.org. 2021.

18. Recommendations of the AGO Breast Committee: Diagnosis and Treatment of Patients with early and advanced Breast Cancer, www.ago-online.de. 2021.

19. Pappo I, Wasserman I, Halevy A. Ductal carcinoma in situ of the breast in men: a review. Clin Breast Cancer. 2005;6(4):310-314.

20. Anderson WF, Althuis MD, Brinton LA, Devesa SS. Is male breast cancer similar or different than female breast cancer? Breast Cancer Res Treat. 2004:83(1):77-86.

21. Hittmair AP, Lininger RA, Tavassoli FA. Ductal carcinoma in situ (DCIS) in the male breast: a morphologic study of 84 cases of pure DCIS and 30 cases of DCIS associated with invasive carcinoma--a preliminary report. Cancer. 1998:83(10):2139-2149.

22. Cutuli B, Dilhuydy JM, De Lafontan B, Berlie J, Lacroze M, Lesaunier F, et al. Ductal carcinoma in situ of the male breast. Analysis of 31 cases. Eur $\mathrm{J}$ Cancer. 1997;33(1):35-38.

23. Wellings SR, Jensen HM, Marcum RG. An atlas of subgross pathology of the human breast with special reference to possible precancerous lesions. J Natl Cancer Inst. 1975;55(2):231-273.

24. Shaaban AM. Pathology of the male breast. Diagnostic Histopathology, MINI-SYMPOSIUM: BREAST PATHOLOGY. 2019;25(4):138-142.

25. Simmons RM. Male ductal carcinoma in situ presenting as bloody nipple discharge: a case report and literature review. Breast J. 2002;8(2):112-114.

26. Armstrong J, Saunders C, Metcalf C. Male breast ductal carcinoma in situ. ANZ J Surg. 2003;73(9):774-775.

27. Brents M, Hancock J. Ductal Carcinoma In situ of the Male Breast. Breast Care (Basel) 2016, 11(4):288-290.

28. Zaesim A, Nguyen V, Scarborough CS. Pure low-grade DCIS in a male patient: a case report. J Surg Case Rep. 2018;2018(5):rjy109.

29. Young R GK, Kalnicki S, Fox JL. High-grade Ductal Carcinoma In Situ (DCIS) of the Male Breast Treated with Breast Conserving Therapy. Ann Clin Case Rep. 2017;2:1383.

30. Chern J, Liao L, Baraldi R, Tinney E, Hendershott K, Germaine P. Case report: ductal carcinoma in situ in the male breast. Case Rep Radiol 2012, 2012:532527.

31. Reinhardt F, Mathys B, Reinecke P, Neubauer $H$, Fehm T, Mohrmann S. Magnetic resonance imaging findings of high-grade ductal carcinoma in situ of the male breast: A case report. SAGE Open Med Case Rep. 2018;6: $2050313 \times 18781727$.

32. Basham VM, Lipscombe JM, Ward JM, Gayther SA, Ponder BA, Easton DF, et al. BRCA1 and BRCA2 mutations in a population-based study of male breast cancer. Breast Cancer Res. 2002;4(1):R2.

33. Fentiman I: Male breast cancer: a review. Ecancermedicalscience 2009, 3:140.

34. Harnden DG, Maclean N, Langlands A0: Carcinoma of the breast and Klinefelter's syndrome. J Med Genet. 1971;8(4):460-461.

35. Fackenthal JD, Marsh DJ, Richardson AL, Cummings SA, Eng C, Robinson BG, Olopade Ol: Male breast cancer in Cowden syndrome patients with germline PTEN mutations. J Med Genet. 2001;38(3):159-164.

36. Olsson H, Bladstrom A, Alm P: Male gynecomastia and risk for malignant tumours - a cohort study. BMC Cancer. 2002;2(1):26.

37. Fentiman IS, Fourquet A, Hortobagyi GN: Male breast cancer. Lancet. 2006; 367(9510):595-604.

38. Deacon SJ, Walker RA, Rew DA: Ductal carcinoma in situ in the male breast presenting as a profuse watery nipple discharge: a case report. Eur J Surg Oncol. 1997;23(6):569.

39. Leibou L, Herman O, Frand J, Kramer E, Mordechai S: Paget's disease of the male breast with underlying ductal carcinoma in situ. Isr Med Assoc J. 2015;17(1):64-65.

40. Rodríguez-Fernández V, Cameselle-Cortizo L, Lamas González MJ, De Castro Parga GJ, Valdés-Pons J, Novo Domínguez A, et al. Paget’s disease of the male breast: An unusual case in a young man and literature review. Current Problems in Cancer: Case Reports. 2020;1:100019.

41. Bodnar M, Miller OF, 3rd, Tyler W. Paget's disease of the male breast associated with intraductal carcinoma. J Am Acad Dermatol. 1999;40(5 Pt 2):829-831.

42. Nakamura S, Ishida-Yamamoto A, Takahashi H, Hashimoto Y, Yokoo H, lizuka H. Pigmented Paget's disease of the male breast: report of a case. Dermatology. 2001;202(2):134-137. 